\title{
Temporal and spatial changes in the distribution of heaths within the city of Torun according to analysis of cartographic and remote-sensing materials, and field exploration
}

\author{
*Mieczysław Kunz, **Andrzej Nienartowicz \\ * Department of Cartography, Remote Sensing and GIS, Institute of Geography, \\ ** Laboratory of Ecological Processes Modelling, Institute of Ecology and Environment Protection, \\ Faculty of Biology and Earth Sciences, Nicolaus Copernicus University, \\ Gagarina 9, 87-100 Toruń, Poland \\ e-mail: met@umk.pl
}

\begin{abstract}
The paper describes changes in the distribution and the surface area of heaths during the last, nearly 120 years at two research sites located in the city of Torun. The first site „JAR” is a former land of military manoeuvres in the northern part of the city, where a unit of the Soviet Army had been stationed after the 2nd World War till 1991. The second site „Glinki”, situated at the south-western end of the city, was also exploited as a military land. During the 2nd World War, a German prisoner-of-war camp was located here, and after the war some industrial plants were built and allotment gardens were established, whereas part of the area was treated as a wasteland. The history of both areas and the vegetation changes were reconstructed from the series of temporal topographic maps and aerial photos, as well as a high-resolution IKONOS satellite image. The aforementioned source materials were analysed with the technology of Geographical Information Systems, applying the software Arc-GIS ArcView 9.3. For both sites, the range was determined, as well as the number of patches with common heather and the total area of heaths in particular years of land cover and land use mapping. The present state of heaths was defined based on the direct field exploration carried out with the use of GPS navigational devices. It was found that at present 22 heather patches occur at the site JAR, with the total area of 11.7328 ha. Within the Glinki district, also 22 heather patches occur with the total area of 3.5701 ha. And thus, these are the largest sites of heaths located within the administrative boundaries of Torun. Data collected through the field exploration of the site JAR were superimposed on the spatial development plan of the future housing estate. At an intersection of both information layers, fragments of the area were outlined where heaths can be preserved after the construction of a housing estate is completed. Their area is small. In the area of the Glinki district, the rate of expansion of industrial areas was determined for the last several years, as well as future changes in the land use were discussed, which will arise due to a housing estate scheduled for building here. The aforementioned analyses enabled to evaluate the present developmental state of both research areas, as well as to determine the future of low shrub communities, which occur here and which constitute a type of an ecological system listed among the UE protected habitats. The obtained results increase our knowledge on heaths in Torun, and at the same time - also in Poland and in Europe.
\end{abstract}

Key words: active nature protection, afforestation of dunes, air photographs, Arctostaphylos uva-ursi, Calluna vulgaris, former military area, fortifications, GIS, GPS, protection of heaths, historical maps, IKONOS, settlement management plan, remote sensing, urbanization.

\section{Introduction}

Heaths as phytocoenotic systems are extremely interesting from the natural, ecological and historical point of view. For the above reasons, they often constitute an object of multifaceted analyses carried out within the framework of international research programmes, as well as they were included on the European list Natura 2000 in compliance with the Habitat Directive. They occur mainly in deforested areas and on the edges of forests. They can be found 
both in economic forests, as well as in some national and landscape parks. Within forest complexes, they grow on electricity power lines and section lines, roadsides and firebreaks, forming rather small clusters of low shrubs. Much larger patches occur in open areas, particularly on former and contemporary military training grounds. In the areas located within administrative boundaries of urban centres, heaths occur rather seldom. One of the exceptions in this respect is the city of Torun, where one can find large heath patches in the areas included within the contemporary administrative boundaries of this city. The city is situated in the Torun Valley, where inland dunes covered with forest occur on quite large areas. In the past it was a stronghold at the Prussian-Russian border. The necessity to expose the stronghold's foreland brought about cutting down the forests and the development of extensive heaths at their peripheries. Large or smaller military training grounds maintained at the peripheries of the city and at the stronghold's foreland created favourable conditions for the development of formations of low shrubs. In the past, heaths occurred here abundantly. At present, as a consequence of human activity, this interesting vegetation formation is rather disappearing.

Documentary studies were being conducted at two research sites, where heaths occurred in the past and persisted to this day. These areas are located within the administrative boundaries of Torun: 1 - the research site JAR, which at present constitutes an area of the planned residential district and till 1991 - the garrison and manoeuvre area for an unit of the Soviet Army; 2 - the Glinki district - the area with interesting history, where even today there are large areas of heaths, and the main threats are road investments and related contamination of the atmosphere coming from the motor traffic and urbanization. The present paper aims at describing the transformations, which take place during the last century at both heath areas, as well as at describing their present distribution and determining the threats, which will intensify in the nearest future. The history of the development of heaths at both sites was analysed with the GIS technology, based on historical and contemporary cartographic and remote-sensing materials.

\section{The study area}

The research site JAR is located in the northern part of Torun between the street Grudziądzka, which turns into the road A1 Torun - Gdańsk, as well as streets Ugory, Polna and the northern boundary of the city (Fig. 1). It is situated at the foreland of fort $\mathrm{V}$, one of 15 defensive elements of this type from the former Prussian stronghold Thorn. Fort V (formerly III Scharnhorst, at present Jan Karol Chodkiewicz) was erected in 1878-1884 as a northern part of the defensive line of the city and defence of a railway line to Grudziądz.

The location of the research plot JAR, as well as the research plot Glinki and the site Zadroże Dune are presented on a topographic map of the whole territory of Torun and its surroundings, which is included in another paper of this issue of Ecological Questions.

The research plot JAR is separated from the nearby residential district Wrzosy (located west of JAR) by a zone of forests, mainly young pine growths, included within the Forest Division of Torun. Also a strip of old pine forest is included within this forest division, which separates the JAR area from the road A1.

In the 19th century, a manor existed within the territory of the present-day district Wrzosy. From the beginning of the 20th century, this part of Torun has been developing as a villa district. Recently apart from low residential buildings, multi-family houses are being built, mainly 5-storey buildings. Whereas, the research area of JAR was uninhabited and overgrown with pine forest until the 19th century. In the 19th century, the area was exploited by the Prussian cavalry for manoeuvres. In 1916, an ammunition depot was built in this area, as well as a system of roads and railway sidings was developed. During the interwar period, the area was also exploited by the Polish army. In 1940, the area of the ammunition depot was extended up to the size of the whole present-day JAR area. In 1945-1991, this was the place where the Engineer Pontoon Battalion was stationed together with its equipment park, as well as air force units and depots of the Soviet Army. It is where the name of the research area JAR comes from- the Unit of the Soviet Army (in Polish - Jednostka Armii Radzieckiej).

The central part of the JAR area is afforested. A strip of ground devoid of vegetation ran around the forest complex. The whole area was surrounded by a double barbed-wire fence. Between the two wire fences, a road hardened with limestone rubble ran, along which a guard was walking.

After the Soviet Army left this area in 1991, the land was quickly transformed into wastelands, dominated by wilding pine trees and heather. Also psammophilous species encroached on the area; the association Spergulo-Corynephoretum developed here. Double embankments were built inside the fences around the forest complex. The existing dune hills were used for their construction. Shooting ranges were located between the embankments.

The terrain was intersected by concrete roads and ditches connecting the observation points, fire stations and military hardware warehouses. Warehouses are situated in the southern part of the area. From the south, there are boards with information on the danger of explosions and entry ban. Nevertheless, the area is still penetrated by people, particularly from the side of the residential district of Wrzosy, from which it is separated by a strip of forest. The forests are under the administration of the Forest Division 


\section{Polish National Coordinate System 1992}

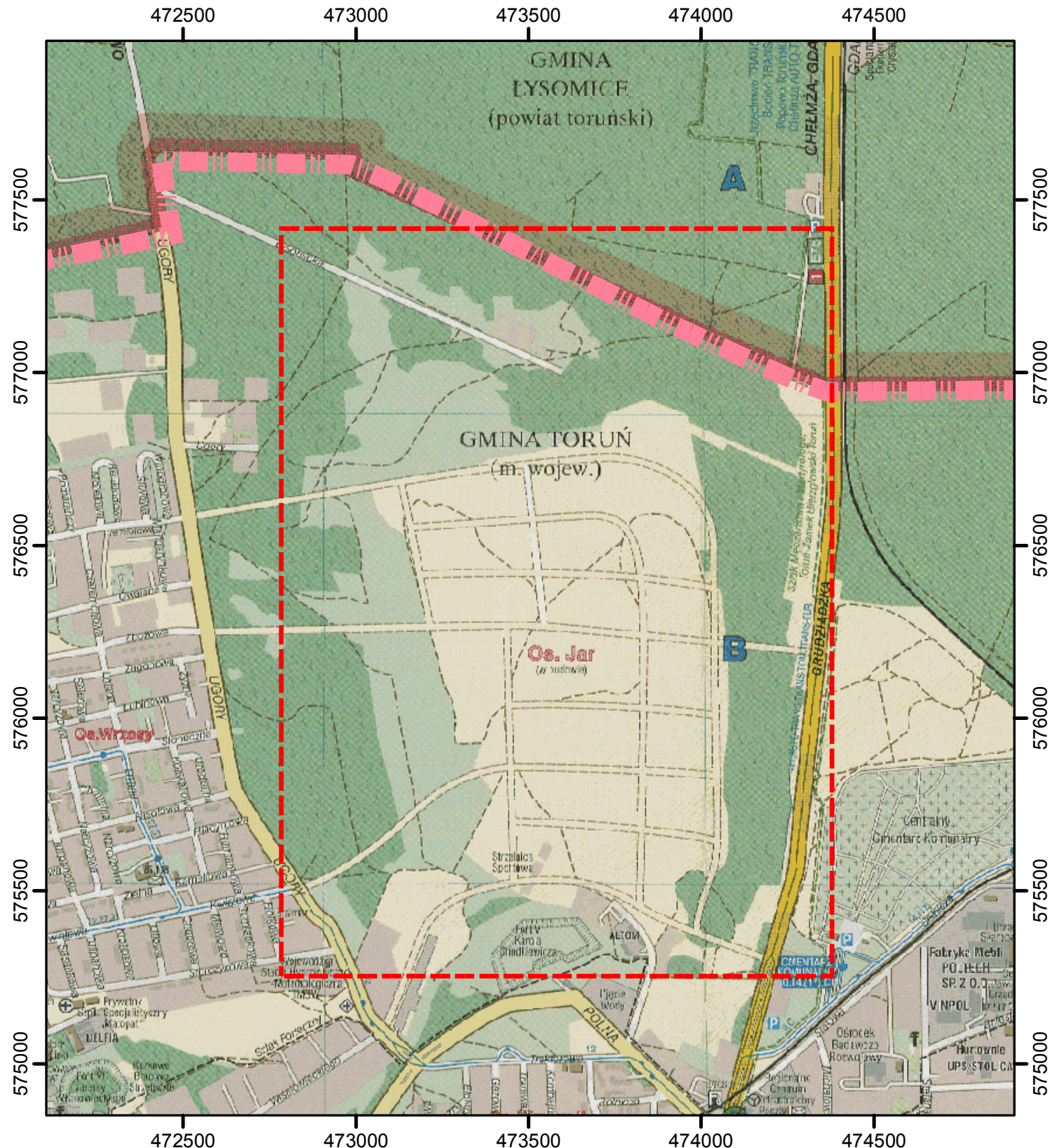

- the JAR study area limits

\section{the boundary of the city of Torun}

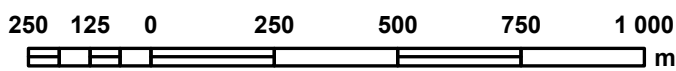

Figure 1. Location of the site JAR on the street plan of Torun from 2007

of Toruń, with the registered office by Polna Street. This street constitutes the former military motor road connecting the main strongholds and infantry, artillery and ammunition bunkers. In the eastern and northern part of the JAR area, a high voltage power line runs, which supplies the city of Torun with electric energy. In the vicinity of the research site, at the junction of streets Grudziądzka and Polna, the Main Power Supply Station is located. The general direction of the power line is from north-west to south-east. Under the power line, wilding pine trees are 
being removed every few years, which is favourable to the development of heaths and psammophilous grasslands.

After the Soviet Army left the area, the decision was taken to build a housing estate in this place for 18-20 thousand people. It will comprise the commercial building sector on the eastern side along the road A1, the sector of multi-family housing construction in the southern part and the sector of single-family housing construction in the northern part of the area. The management plan of the residential district JAR was enacted on March 1, 2007 (http://pl. Wilkipedia.org/Wiki/JAR/Torun). The terrain was measured and inspected by sappers. The sale of plots should begin in 2010 .

The research area of Glinki is situated on the left bank of the Vistula River and it constitutes the most south-westward limits of the city. It is a triangle situated between the following roads: the former road running towards the town of Inowrocław and Poznań and the parallel, new ring road of Torun, running in the more south-western direction, (the southern ring road of Torun, also called the route of the military training ground), a new route towards Bydgoszcz built in the 1980s (a section of the national road S10 Warszawa - Szczecin, marked on street plans as Gniewkowska Street, together with its branch towards Inowrocław and Poznań) and railway lines Torun - Bydgoszcz - Inowrocław. From the north-west, the Glinki area borders on the Zadroże Dune situated behind the railway track and outside the city limits, and from the south and the south-west on the military training ground, situated behind a new ring road of Torun. From the north, behind the exit road to Bydgoszcz and Szczecin, the residential district Glinki is located, one of the smallest residential districts in Torun with a small number of residents. In the territory between Szubińska Street (the former road to Bydgoszcz) and the new road S10 (Gniewkowska Street), a church was built dedicated to the Blessed Father Stefan Wincenty Frelichowski.

In the 19th century and at the beginning of the 20th century, the area was used as a field for military manoeuvres. During the 2nd World War, the POW camp Stalag XX was located here, where at first British and French prisoners were kept, and since 1941 - Russian prisoners (Tyszkiewicz 1976). Particularly Russian POWs were kept in cruel conditions. At that time, the area of the camp was called „Soviet Heide”. More than 12 thousand Russian prisoners died in the camp. They were buried on the nearby cemetery, located next to the Zadroże Dune.

After the 2nd World War, in the 1950s, temporary buildings of Pomorskie Zakłady Drobiarskie (the Pomeranian Poultry Plants) were built in the eastern part of the Glinki area. In the 1970s, the plant was extended. A new office block was erected and floors for fattening of poultry, slaughter of birds and initial processing of products. During the 1990s after privatization, the plant was taken over by the company „Drosed” from the French group LDC. In
January 2008, the plant burnt to the ground. The Company made the decision not to reconstruct the factory. A project is considered to build a housing estate in the place of the burnt plant.

During the last years, the built-up area at the research site of Glinki was extended. In the territory bordering from the west on the factory Drosed, warehouses were created with building materials and cobblestones of the Danish company IBF, the bus depot PKS and the distribution centre of trucks DAF. Buildings are also to be found at the very south-western end of the research area, where the headquarters of the Glinki forest district are located, included in the Forest Division of Gniewkowo.

Whereas on the north-western side of the plant Drosed, employees' allotment gardens were established in the 1980s. Garden soil was brought on the dune sands, roads were marked out, garden houses were built and the area was enclosed. Few years ago, the crest of the dune located further west, was broke up by bulldozers. The area was levelled, the southern ring road of Torun was marked out and then built, together with a road junction that enables connection with other communications routes.

Today, the triangular part of the Glinki research area, which was not built-up or turned into allotment gardens, is overgrown with heather patches, psammophilous grasslands Spergulo-Corynephoretum and Calamagrostio epigeji, as well as patches of lichens from the genera Cladonia and Cetraria, and mosses, mainly Polytrichum piliferum. In the past, these plant communities were studied here by Wilkoń-Michalska and Symonides (1974), as well as by Symonides (1974a, b, c, d; 1979 a, b, c; 1985). Forest is the biggest threat to these open communities. The pine encroach most intensively from the western and north-western side, where the area borders on the vast complex of the Bydgoszcz-Torun Forest. The area is devastated by illegal waste dumping. In the south, transport pollution and trampling down pose a threat, as well as taking over the area by bus termini and mini football pitches arranged spontaneously by young people.

\section{Research methods}

In the research on the occurrence range of heaths at both sites, historical and contemporary topographic maps were used, as well as aerial photos and a high-resolution satellite image Ikonos. In the case of the JAR area, the oldest maps came from 1892 and 1934. The oldest maps of the site Glinki covered the years of 1909 and 1936. Maps describing the three subsequent states, in both cases concerned the years of 1963, 1971 and 1987. The latter one, i.e. the youngest state of the JAR area was evaluated based on the topographic map from 2003, whereas the Glinki area, based on the map from 2000. The map from 2000 was drawn up 
at the scale of $1: 10,000$, all the other maps were at the scale of 1:25,000. Aerial photos of the JAR area were made in $1975,1996,2004$ and 2008. In the analysis of changes in the distribution of heaths at the Glinki site, aerial photos were used from 1961, 1974, 1996 and 2004. The satellite image Ikonos of both research areas came from August 19, 2005. The location of both sites and changes in their land use and land cover were also analysed in compliance with street plans of Torun, published in 1994 (the original scale 1:20,000), 1997 (1:15,000), 2000 (1:20,000) and 2007 (1:18,000).

For a more precise location of places where heaths occurred in 2009, the geodesic TopCon HiperPro GPS receiver was used. Field coordinates were obtained in the RTK mode (Real Time Kinematic) and corrections of coordinates were obtained from the ASG-EUPOS network. The location results were collected in the form of dots. Also the surface area was defined for particular vegetation patches dominated by common heather - Calluna vulgaris, as well as the total area covered by patches of this dwarf shrub. Also the location of some species, such as Arctostaphylos uva-ursi and Pulsatilla pratensis, was determined.

Further research work was conducted with the GIS technology, using our licensed software packages to gather and process the data. This work is a part of a broader project, which aims at compiling the range and analysing the spatial variability of heaths in northwestern Poland. Data on the contemporary location of heaths, after being processed with the desktop software Arc GIS ArcView 9.3, were presented on the topographic map in the form of polygons. After completing the procedure of georeferencing and geometrical rectification of all cartographic and remote-sensing materials, the area of heather patches was plotted at both sites in all previous developmental states. Apart from heather patches on the areas of JAR and Glinki, polygons with the following land cover forms were identified: forest, bare sand, sands sparsely covered with vegetation, a xerothermic meadow, industrial areas, allotment gardens, built-up areas and water bodies.

The surface area of individual land use categories was read off from particular historical and contemporary maps, as well as from remote-sensing materials. These data were compiled in the table that illustrates temporal changes in land cover of both research areas. Areas of individual polygons with heather, which occur nowadays over the area of JAR and Glinki, were presented in the form of sequences from the largest patch to the smallest one on the joint graph.

Data on the present distribution of heaths over the JAR area, acquired through field measurements were superimposed on the plan of a future housing estate drawn up by the Urban Planning Laboratory in Torun in 2007. As a result of superposition of two information layers, future changes of particular fragments of the research site were determined, as well as the threats posed by urbanization processes to all heather patches occurring within its range.

\section{Results}

\subsection{Heaths of JAR}

On the German topographic map of Torun 1510, sect. Thorn from 1892, the heaths occurring in the northern part of the JAR research area were presented as five patches of very different shapes and sizes (Fig. 2A, Fig. 4A). The largest of them had the area of 7.8665 ha and the smallest one - about 1.4968 ha. The total area of heather patches amounted to 21.0210 ha. Apart from heaths, also forest areas occurred in the studied area, situated mainly in the central-western part and more to the north of the heather patches. A small forest complex also occurred in the eastern part of the JAR area. Built-up areas and areas exploited by a local population as grazing and agricultural lands are mainly located in its northern area. In the central, sandy part of the area, the military training ground is situated and in the south-western part - some buildings, which were certainly used by the Prussian army.

There are no industrial plants on the map or any other larger infrastructure important from the strategic point of view.

Figure 2B is another German topographic map 2977 sect. Thorn from 1936 (1:25,000), which presents the city area from the period between the 1st and the 2nd World War. In the central part of the research area, one can see some facilities of an ammunition factory, which was erected at the foreland of the stronghold V, as well as military warehouses and fragments of a railway line and a railway siding. Around these facilities there are heathlands. Heather patches are particularly abundant on the eastern and the south-western side of the military facilities (Fig. 4B). There are 17 heather patches and their total area amounted to 128.3260 ha, what constituted $37.21 \%$ of the whole JAR area (344.8672 ha). The size of the largest patch was 66.2666 ha and the smallest one - only 0.3203 ha. In the northern part of the research area, forests and buildings occur, as well as agricultural lands of the village Lisi Ogon. On the map, also hardened roads and tracks are plotted, which at that time ran through the studied area.

From the topographic map of 1963 (Fig. 2C), it appears that the area of JAR was dominated by non-forest communities. However, no heaths were distinguished among them, which certainly does not mean that such plant communities did not occur within the JAR area in the early 1960s. Whereas, the map presents the occurrence of single trees, shrubs and their clusters of different size. They were distributed mainly in the central part of the studied area. In the eastern part of the area, a small complex of young forest was located. 


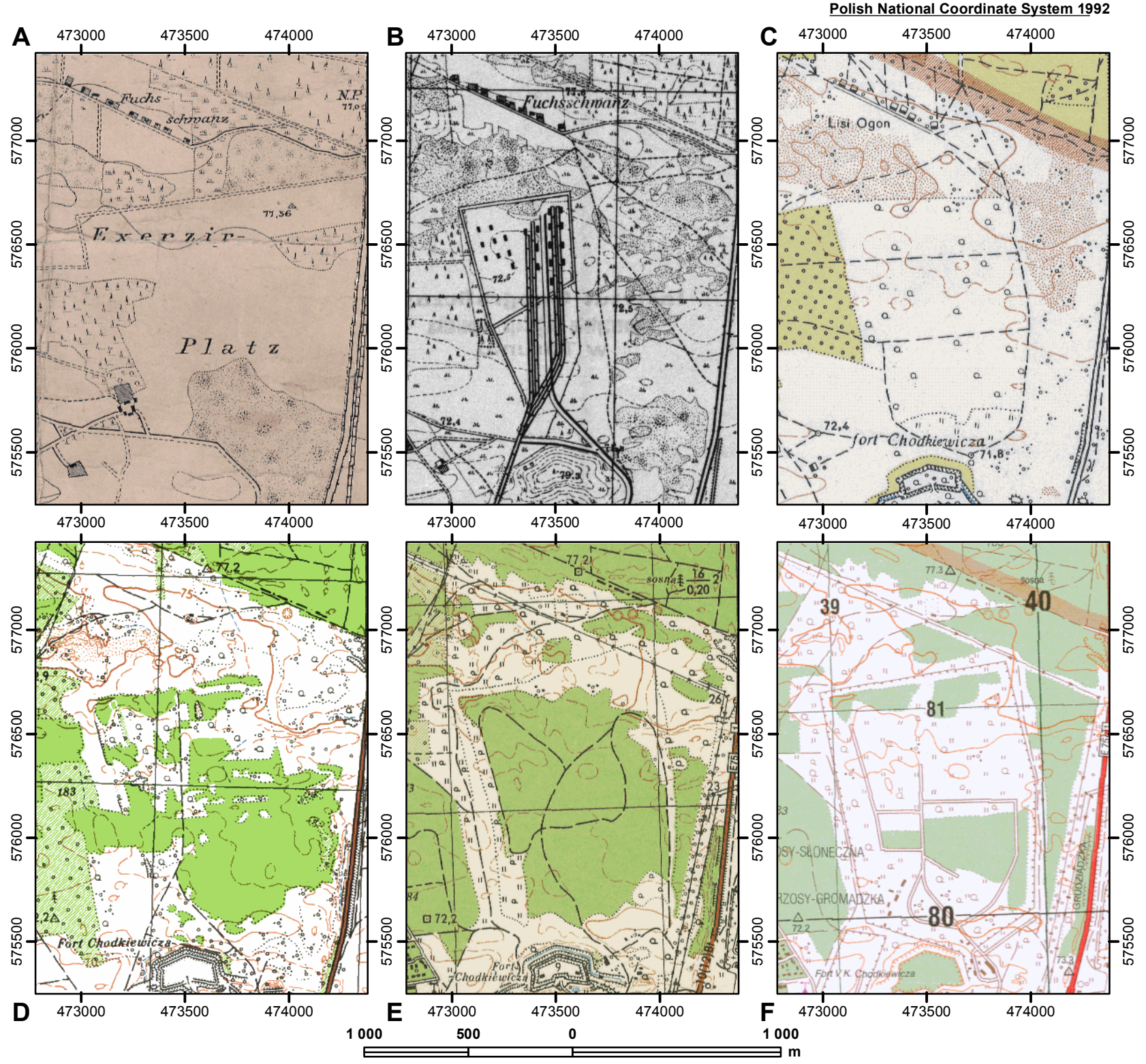

Figure 2. Changes in the JAR area on the temporal series of topographic maps (A - Prussian topographic map from 1892, the original scale 1:25,000, sheet 1510 Thorn; B - German topographic map from 1936, the original scale $1: 25,000$, sheet 2977 Thorn; C - topographic map from 1963, the original scale 1:25,000, sheet no. 5; D - topographic map from 1971, the original scale 1:25,000, sheet 355.14 Łysomice; E - topographic map from 1987, the original scale 1:25,000, sheet N-34-98-C-c Toruń; F - topographic map from 2003, the original scale 1:25,000, sheet N-34-98-C-C,D Torun - 1)

On the two other maps: 355.14 , the sheet of Łysomice from 1971 and N-34-98-C-c, the sheet of Torun from 1987 (Fig. 2D, 2E respectively), a gradual increase in the range of forests on the JAR area is evident. On the former map, the forest occurring in the central part of the area is characterized by considerable fragmentation. On the map from 1987, a dense forest complex is located in the central part of the map. When comparing the map from 1971 with the aerial photo from 1975 (Fig. 3A), it appears that high saturation of the area with newly erected fortifications and military equipment was the cause of strong fragmentation of the forest complex and consequently the smaller forest area during this period as compared with the state of 1987. No heaths were distinguished on the maps from both periods, i.e. 1971 and 1987. Most probably they occurred mainly along forest edges, especially in the northern part of the 


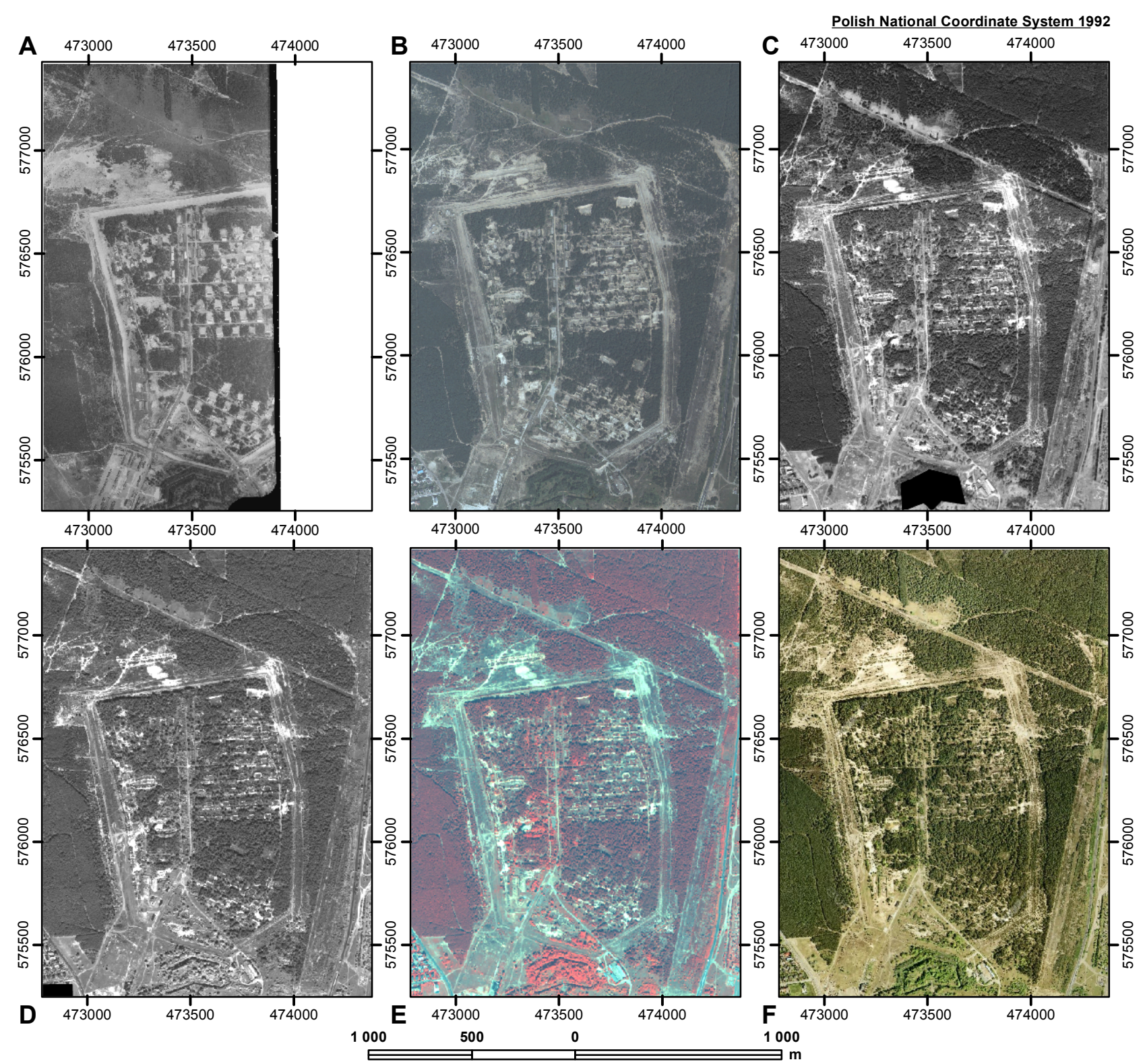

Figure 3. Changes in the land cover/land use of JAR in aerial and satellite photographs (A- panchromatic aerial photo from 1975, the original scale 1:16,000; B - colour aerial photo from 1996, the original scale 1:26,000; C - panchromatic orthophotomap from 2004, the original scale 1:10,000; D - panchromatic satellite imagery IKONOS from August 2005; E - colour satellite imagery IKONOS from August 2005; F - colour aerial photo from 2008, digital photo)

analysed JAR area. This kind of distribution was observed during the field observations in 2009.

In comparison with the map from 1987 (Fig. 2E), the map from 2003 (Fig. 2F) reveals the disappearance of forest areas in the central part of the study area. However, similarly like on the earlier map, places with heaths were not plotted. As compared with the map from 16 years ago, on the map from 2003, there are buildings in the southern part of the JAR area and new tracks in its central part. Whereas, when comparing the map from 2003 with aerial photos of this area from 1996 and 2004 (Fig. 3B and 3C), as well as with satellite images Ikonos from August 2005, presented in the panchromatic and coloured mode (Fig. 3D and $3 \mathrm{E}$ ), one can draw a conclusion that the mapping of forests was done with rather little accuracy. Because in the central part of the research site there are more forest 


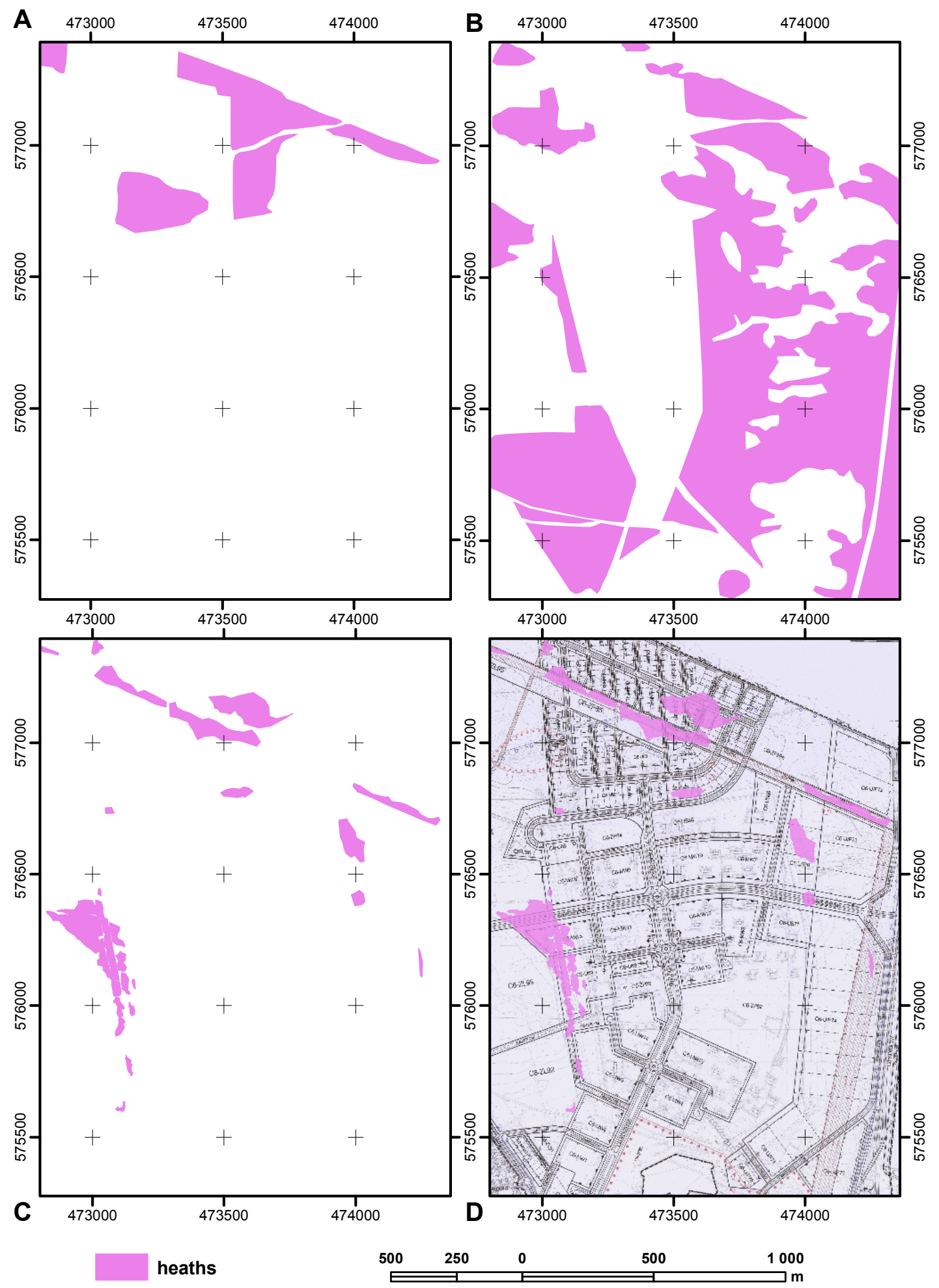

Figure 4. The size, shape and the spatial distribution of vegetation patches dominated by heather over the research area JAR (A - in 1992, determined on the basis of the topographic map at the scale of 1:25,000; B - in 1936, based on the topographic map at the scale of 1:25,000; $\mathrm{C}$ - based on the field research and measurements by a GPS receiver; D - the range of heather patches in 2009, superimposed on the spatial development plan of the housing estate JAR prepared by the Urban Planning Laboratory of the Municipal Council of Toruń) 
areas on the remote sensing materials than it was plotted on the map.

The newest aerial photo from 2008 (Fig. 3F) reveals the extent of vegetation destruction in the studied area after the army left. New footpaths appeared within the unsupervised area, as well as depressions originated as a result of illegal land use by motorcyclists and drivers of quads and racing cars. Those disturbed areas are distinguishable by light background, which are particularly numerous in the northwestern part of JAR.

Nowadays, heather patches occur mainly in the northern and eastern part of JAR (Fig. 4C). They are less abundant on the eastern side of the main area, which until recently was exploited by the army. In the northern part, heather patches occur under a power line, across the research area. In the western part, they concentrate at the end of the road that runs through the forest, facing the residential district of Wrzosy. On the eastern side, patches of low shrubs occur along the road, which constitutes a boundary of the main part of the military ground.

Altogether 22 heather patches occur on the area of JAR. The largest of them is ca. 2.0954 ha in area. It is a patch situated in the western part of the study area from the residential district of Wrzosy. It borders on the forest area and is separated from other heather patches by footpaths developed as a consequence of passing by quads and motorcycles. The smallest polygon has the area of 0.0259 ha and is located between sparse pine trees. The total area of heaths located within the whole JAR site in 2009 came to 11.7328 ha, which constituted $3.4 \%$ of the total study area.

Figure 4D presents the distribution of heather patches in 2009 with reference to the spatial development plan of the future housing estate JAR. Areas allotted for residential and commercial buildings were designated on the plan. New housing estate roads and electricity power lines were marked out, as well as pedestrian and bicycle lanes. The general boundary of the residential district was delimited. This way, there were presented lands, which will remain unchanged, as well as those, which will be transformed. Also future greenery areas were marked on the plan, as well as the current forest lands, which most probably will be preserved. From the superposition of both information layers, performed with the GIS technology, it appears that the majority of the existing heather patches will be destroyed. Only heather patches located on the western side of the JAR research area have the chance to survive.

\subsection{The study area of Glinki}

Intensive changes in the land use of the Glinki area (in total $246.4095 \mathrm{ha}$ ) took place during the last 20 years. They were manifested through the increased number of industrial plants and their increased surface area, creation of allotment gardens and construction of a military training ground (Fig. 5). Particularly, the latter investment triggered off drastic transformations in the southern part of the Glinki area, where heather patches occur abundantly. Changes in the land cover/land use of the most southward, isolated fragment ( 78.7484 ha in area) is presented by the temporal series of topographic maps (Fig. 6). However, the occurrence of heaths was plotted only on the oldest maps of this series, i.e. the Prussian map from 1909 and the German topographic map from 1934 (Fig. 6A and 6B).

Only three heather patches were plotted on the former map, with the total area of 0.843 ha (Fig. 8A). The largest of them covered the area of 0.5051 ha and the smallest one - the area of 0.1029 ha. Sands, probably sparsely covered with dune vegetation, dominated over the remaining part of this area, used for military manoeuvres.

The German map from 1934 covers five polygons determined as a heath (Fig. 8B). Their total area comes to 29.9294 ha, which makes up $38.01 \%$ of the whole studied fragment of the Glinki area. The surface area of the largest patch dominated by Calluna vulgaris comes to 26.4656 ha. It is located in the north-eastern part of the described land. The smallest patch, with the area of 0.0186 ha, is situated in the south-western part of the analysed area. The remaining part is dominated by forests, buildings and communications areas (Fig. 6B).

On the later maps, i.e. from 1963, 1971, 1987 and 2000 (Fig. 6C, 6D, 6E and 6F), heaths were not distinguished among land cover forms. Gradual increase in the contribution of forest area is evident in this temporal sequence, particularly in the western part of the study area and in its immediate surroundings. This is confirmed by aerial photos from 1961 (Fig. 7A) and 1975 (Fig. 7B). However, within the analysed triangle, definitely non-forest communities dominate. On the map from 1971 in the northeastern part of the area, some industrial areas are visible. Their surface area did not increase on the maps from 1987 and 2000. On the map from 2000, in the northern part of the described area, allotment gardens are plotted near the railway line. They were created in the 1980s. They are not marked on the map from 1987, however they are present on the aerial photo from 1996 (Fig. 7C). The aerial photo from 2004 (Fig. 7D) and the satellite images Ikonos from 2005 in the panchromatic (Fig. 7E) and multispectral mode (Fig. 7F) reveal significant transformations in the studied area, induced mainly by construction of the new communications route - the ring road of Torun, and the development of new industrial plants on its northern side. According to the map from 1987, the communications lands were 3.17 ha in area, whereas the industrial lands - about 4.88 ha, i.e. respectively $4.06 \%$ and $6.20 \%$ of the whole studied part of the Glinki site (78.7483 ha). According to the aerial photo from 2005, the surface area of the communications lands increased to 7.69 ha and the 


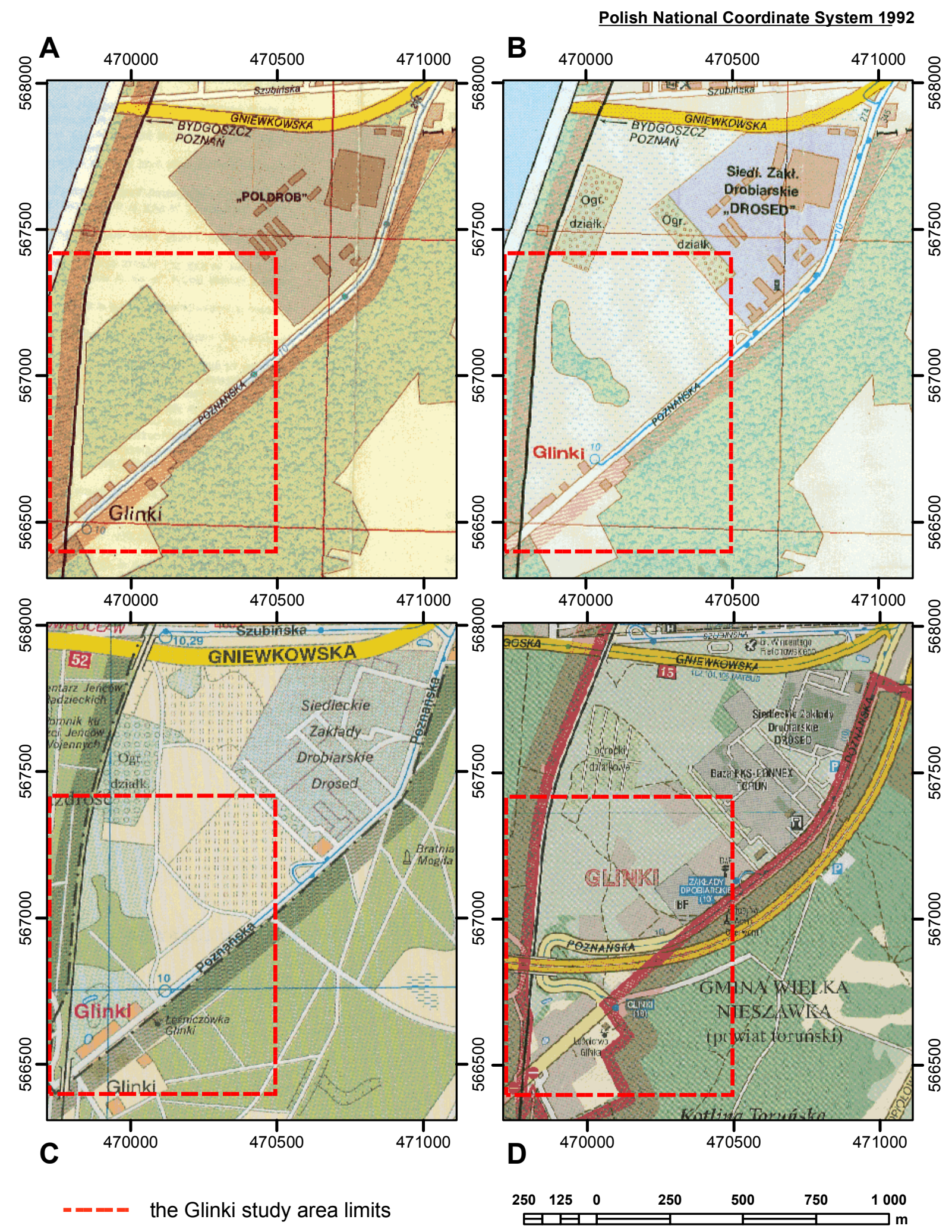

Figure 5. Location of the area Glinki and changes in the land use on the temporal series of street plans of Torun (A - street plan of Torun from 1994, the original scale 1:20,000; B - street plan of Torun from 1997, the original scale 1:15,000; B - street plan of Torun from 2000, the original scale 1:20,000; B - street plan of Torun from 2007, the original scale 1:18,000) 


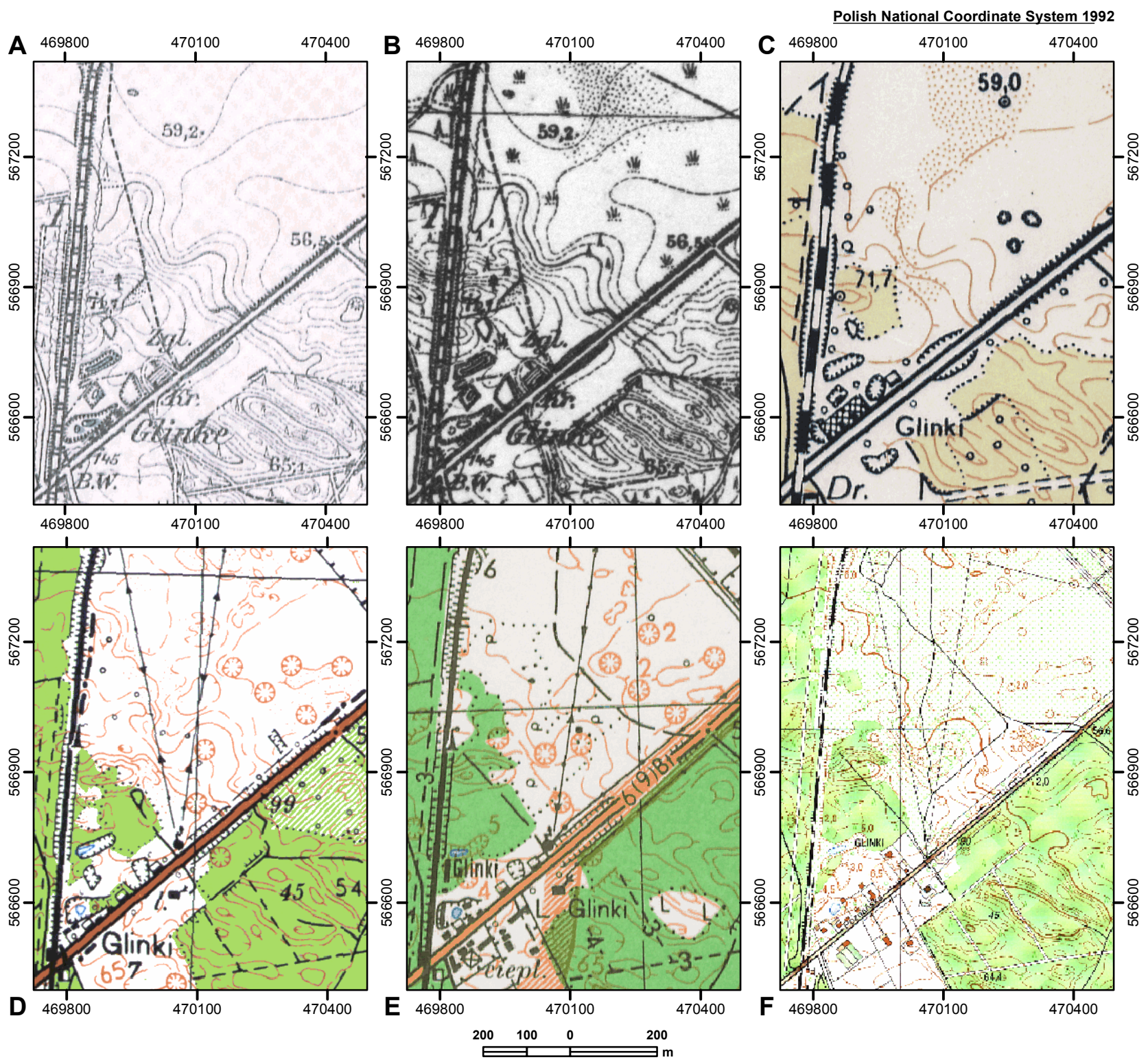

Figure 6. Changes in the land cover in the southern fragment of the area Glinki on the temporal series of topographic maps (A Prussian topographic map from 1909, the original scale 1:25,000, sheet 1583 Podgorz; B - German topographic map from 1934, the original scale 1:25,000, sheet 3077 Podgorz; C - topographic map from 1963, scale 1:25,000, sheet no. 8; D - topographic map from 1971, the original scale 1:25,000, sheet 355.32 Toruń; E - topographic map from 1987, the original scale 1:25,000, sheet N-34-110-A-a Podgórz; F - topographic map from 2000, the original scale 1:10,000, sheet N-34-110-A-a-1 Mała Nieszawka) 


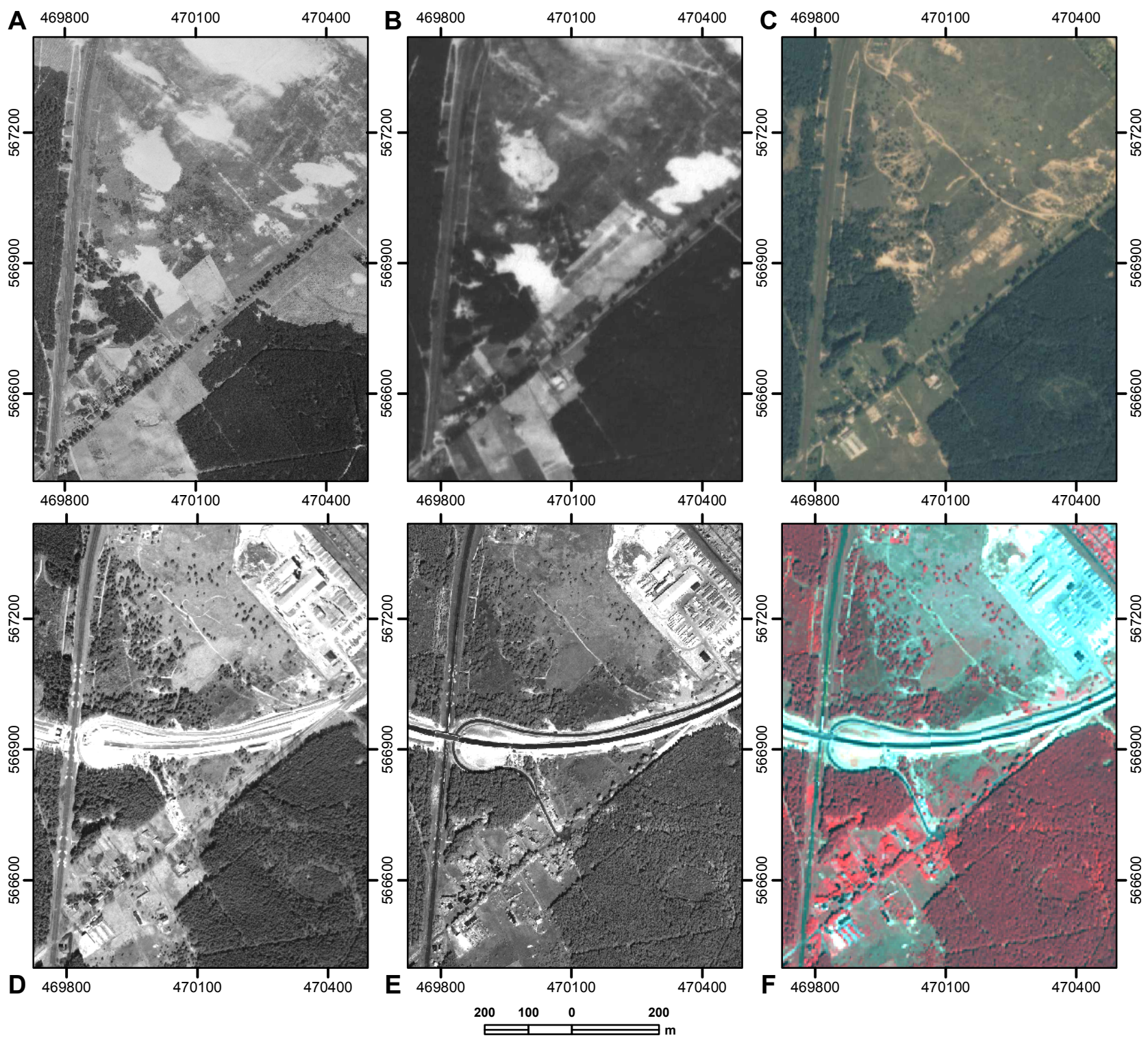

Figure 7. Changes in the land cover in the southern fragment of the area Glinki on the temporal series of aerial and satellite images (A - panchromatic aerial photo from 1961, the original scale 1:13,500; B - panchromatic aerial photo from 1974, the original scale 1:25,000; B - colour aerial photo from 1996, the original scale 1:26,000; C - panchromatic orthophotomap from 2004, the original scale 1:10,000; D - panchromatic satellite imagery IKONOS from August 2005; E - colour satellite imagery IKONOS from August 2005)

industrial lands to 13.71 ha, which is $9.77 \%$ and $17.41 \%$ of the total area respectively.

Based on the analysis of the satellite image and the field exploration of the area, it was found that in 2009 there were 22 patches of common heather in the studied area, similarly like on the JAR area. Measurements performed with the GPS receiver confirmed that their total area comes to 3.5701 ha. This constitutes $4.53 \%$ of the total area (78.7483 ha) designated for the detailed analysis of the spatial distribution of Calluna vulgaris. The largest patch has the area of 1.8895 ha and the smallest one - only 0.0006 ha. The largest patch is situated on the edge of the forest, which developed from self-seeding of pine along railway tracks (Fig. 7E, 7F and $8 \mathrm{C}$ ). The other two largest polygons, dominated by Calluna vulgaris, are situated more to the east, closer to industrial areas. These patches are adjacent to psammophilous grasslands dominated by Corynephorus canescens and Calamagrostis epigejos. 


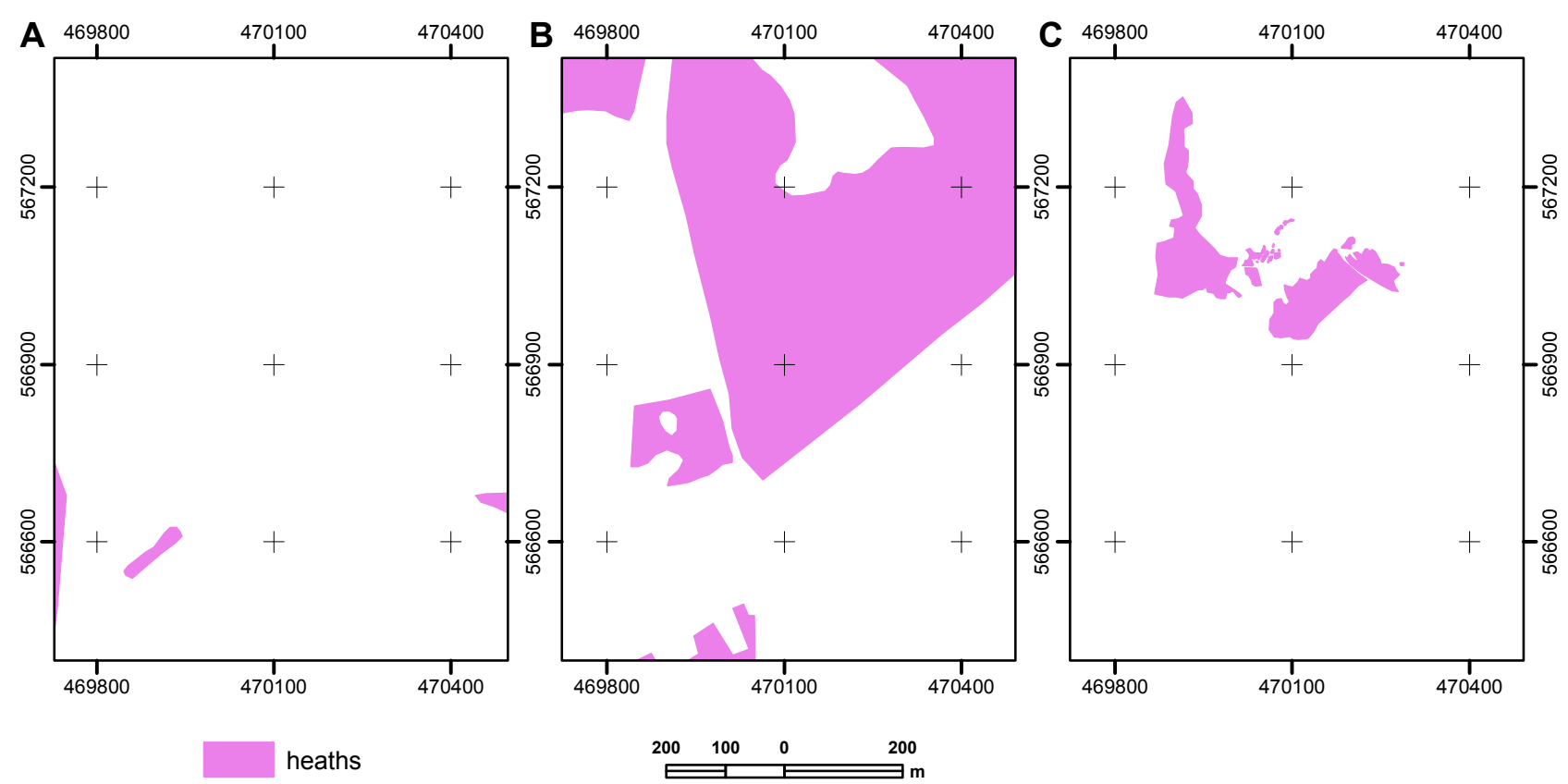

Figure 8. The size, shape and the spatial distribution of vegetation patches dominated by heather over the research area Glinki (A - in 1909, based on the Prussian topographic map; B - in 1934, based on the German topographic map at the scale of 1:25,000; $\mathrm{C}$ - in 2009, determined on the basis of field research and measurements by a GPS receiver)

Boundaries of the others, much smaller heather patches, meet alternately with forest and grassland. Next to some patches, also bicycle lanes run, developed most probably as a consequence of biking to allotment gardens located at the northern part of the studied area.

The size structure of patches dominated by heather at the Glinki site is presented in Fig. 9. From the figure it appears that the number of patches is as small as on the research area of JAR. However, there are only three large patches of heather, whereas on the JAR area - as many as seven patches. For that reason, the curve that illustrates the size of patches of the research area Glinki, arranged from the largest to the smallest one, runs below the curve of the research area JAR.

After completing the detailed field exploration, three sites were characterized with the occurrence of Arctostaphylos $u v a-u r s i-$ a rare and protected plant. One of them is located right next to the ring road, blending in with the patch of the community of Calluna vulgaris, which borders directly on the forest. Whereas, the other site, a little larger than the previous one (ca. $4 \mathrm{~m}^{2}$ ), is surrounded by the xerothermic grassland and is situated not far from the limits of industrial plants. The third site is situated near the pine forest, which developed on the western side in the vicinity of the railway line. Results of these observations will constitute the reference point for further research, which could contribute to protection of sites with this dwarf shrub.

\section{Discussion and conclusions}

From the results of calculations presented in the previous chapter, it appears that the common heather covers a considerable area at both sites. The future of heaths, however, is endangered here. Housing and other industry, as well as building of roads is the main economic sector, which in the near future can bring about the extinction of heaths on both areas. The development of these economic sectors is the cause of losses in the area of heaths also in other countries. Webb (1990), when analysing the development of heaths in the county of Dorset in southern England, found that between 1978 and 1987, the area of heaths decreased by 401 ha, including, 148 ha, i.e. $37 \%$ of the whole decline, which was taken over by housing construction, roads and industry. The aforementioned economic sectors were second on the list of causes responsible for the decrease in the area of heaths. Agriculture was higher on the list. It incorporated 183 ha for cultivation, i.e. $46 \%$ of all transformations in the land cover and land use in the county of Dorset. Losses in the area of heaths due to the increase in recreational areas, extraction of minerals and forestry amounted there to 7.6 and $2 \%$ respectively.

Today, encroachment of forest is the main factor threatening the heaths on the area of JAR and Glinki. History of the Zadroże Dune located near Glinki and described in another paper of the present issue of Ecological Questions 


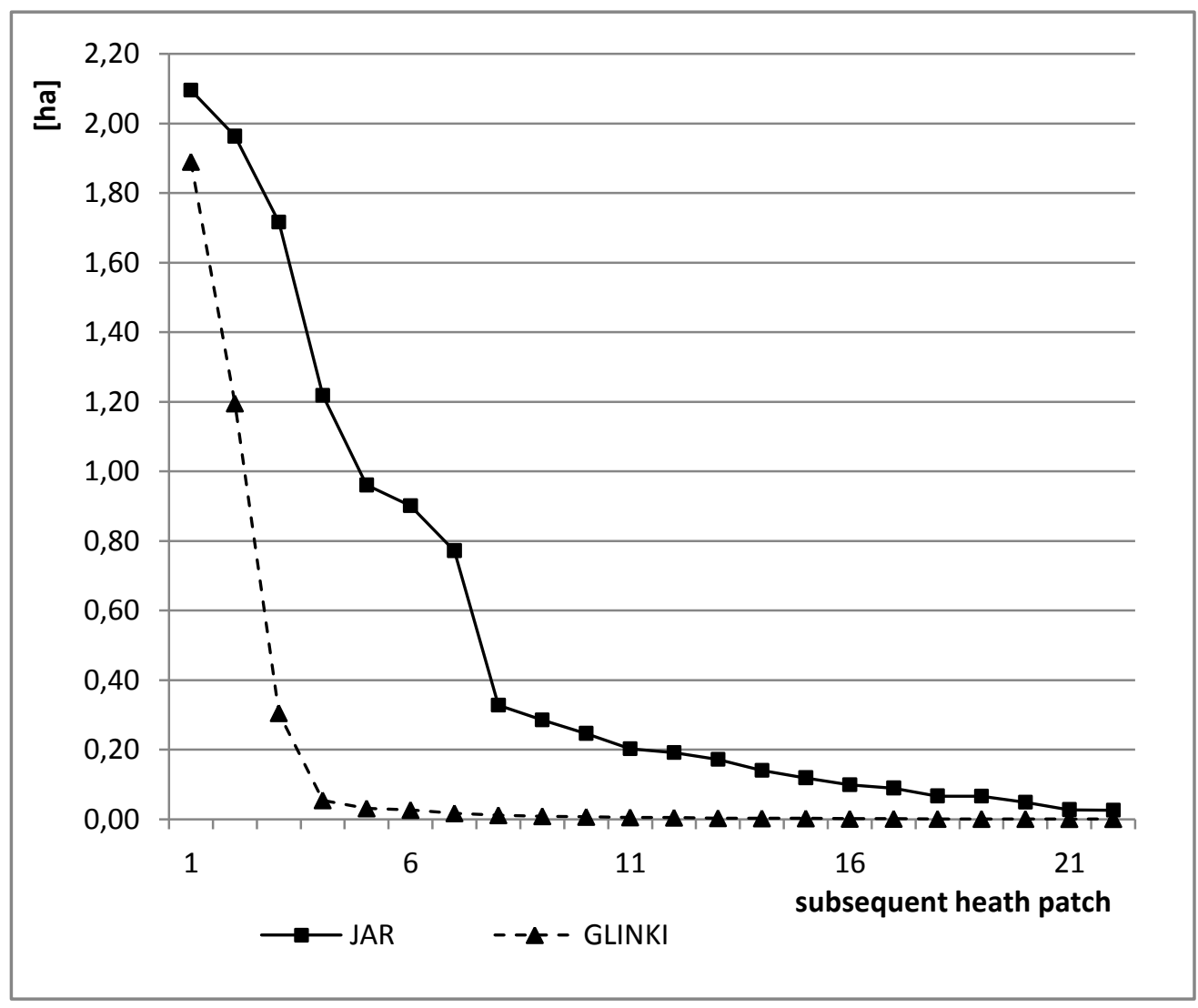

Figure 9. Comparison of the structure of the size of heather patches at the sites JAR and Glinki in 2009

(Nienartowicz et al. 2009), indicates that this can happen due to intentional afforestation implemented by a forest inspectorate. Both at the site of Glinki and at the site of JAR, particularly on its eastern side, in the vicinity of mature pine forest separating the area of the former Soviet artillery range from the road A1 Torun - Gdańsk, spontaneous encroachment of forest is a factor responsible for vanishing of heaths. With reference to this process, Webb (1998) states that in view of extinction of heaths as a consequence of forest succession, active conservation is required, which consists in removing of trees and shrubs, as well as grazing. Changes in the distribution of heaths described in this paper for the period of the last 100-120 years at the sites of JAR and Glinki, as well as changes outlined by Chojnacka et al. (2009) in the distribution of the low-shrub formation in the areas adjacent to the Glinki site, indicate that the factor favourable to preservation of heaths is the military land use. Exposing the area for observations of the fortification's foreland, explosions of shells and grenades, as well as the resulting fires, effectively remove the forest canopy and facilitate the preservation of heather on the sandy substratum in the open landscape.
The conducted research also revealed that in Polish conditions heaths are often treated as wastelands. For a considerable part of the society, they can be entirely allotted for building development. These lands are destroyed by motocross tracks and racetracks for quads, arranged without permission. Both at the site of JAR and at the site of Glinki, the presence of many illegal waste dumps was observed - the cause of eutrophication of the habitat. Among factors unfavourable to the development of heaths at both studied locations, one should certainly mention gas and dust emissions coming from municipal services and road transportation. Both sites are located within the big city and near the roads with high traffic intensity. However, the influence of this factor on the development of heaths was not studied until now. It seems that it is worthwhile to undertake such observations on both areas and neighbouring lands, especially on the artillery range near Glinki.

In the analyses of influence of various ecological factors on the presence and spatial distribution of heaths, the GIS and GPS technology turned out to be a very useful research tool. Also aerial and satellite remote sensing is good a source of information. Veitch et al. (1995), as well as Heil 
and Van Deursen (1997) were one of the first ecologists, who applied the GIS technology to study changes in the distribution of heaths on a permanent large research area. Analysis of heaths based on remote sensing data of the satellite Landsat with the field resolution of $30 \mathrm{~m}$ was carried out by Nordberg and Everston (2003). However, high-resolution Ikonos satellite images proved to be more useful. They were also applied by Allard (2003) in the analysis of extinction of alpine heaths in the territory of Sweden. Also our research proved great usefulness of the GIS methods and satellite remote sensing as a source of information on the distribution of heaths.

Another source of information were maps. However, we found that this type of land cover, such as heaths, is not well reproduced on topographic maps. In the studied temporal series of cartographic materials, their presence is reflected only on the detailed military topographic maps Prussian maps from the end of the 19th century and German maps from the $1930 \mathrm{~s}$.

The present paper revealed that the heaths occurring nowadays abundantly in both parts of Torun are highly endangered due to the spatial development of the city. These systems are worth preserving for natural and historical reasons. This refers particularly to the site Glinki, which is very interesting, both from ecological and historical aspects. Locations of protected plants occurring here, such as Arctostaphylos uva-ursi, Pulsatilla pratensis, Cetraria islandica, relations between abiotic and biotic ecological factors and the structure of plant communities, as well as different developmental phases of plant communities occurring on a small area, significantly enhance nature values of this area. The tragic events from the 2nd World War and relations of these areas with the history of the University of Torun that came to existence in 1945, make this object very interesting from historical aspects. Certainly, it is worthwhile to create an educational and natural trail in this region and to commemorate the events from the past with an appropriate plaque. Perhaps despite the fact that building development plans are scheduled for prompt implementation in this area, at least some fragments of this interesting low-shrub formation could be preserved. However, due to numerous and miscellaneous threats occurring in suburban conditions, this objective will be extremely difficult.

\section{Acknowledgements}

The project is being implemented within the framework of the grant by the Ministry of Science and Higher Education No. N N304 220835. The authors of this paper are grateful to the students of Environment Protection, MSc Marcin Pietrzykowski and MSc Łukasz Wańkowicz, for their assistance in the preliminary identification of the range of certain plant communities in the study areas. We extend our acknowledgments also to the Provincial Fund for Environmental Protection and Water Management in Torun for the financial support, which makes this publication possible.

\section{References}

Allard A., 2003, Detection of vegetation degradation on Swedish mountainous heaths at an elary stage by image interpretation, Ambio 32(8): 510-519.

Gimingham C.H., Chapman S. B. \& Webb N. R., 1979, European Heathlands, [in:] R. L. Specht (ed.) Heathlands and Related Shrublands, Desctiptive Studies. Ecosystems of the World 9A, Elsevier Scientific Publishing Company, Amsterdam - Oxford - New York: 365-413.

Gorissen I., 2004, Die Zwergstrauch-Heiden Europa - vom Atlantic bis zum Kaukasus und Ural (Dwarf skrub heaths of Europe - from Atlantic to Caucasus and Ural), Selbstverlag Ingmar Gorissen, Siegburg.

Heil G. W. \& Van Deursen W. P. A., 1997, Searching for patterns and processes: modeling of vegetation dynamics with Geographical Information Systems and Remote Sensing, Acta Bot. Neerl. 45(4): 543-556.

http://pl. Wilkipedia.org/Wiki/JAR/Torun.

Mapa topograficzna z 1892 r., skala 1:25 000, arkusz 1510 Thorn [Topographic map from 1892, scale 1:25,000, sheet 1510 Thorn], Preuß. Landesaufnahme.

Mapa topograficzna z 1909 r., skala 1:25 000, arkusz 1583 Podgorz [Topographic map from 1909 at the scale of 1:25,000, sheet 1583 Podgorz], Preuß. Landesaufnahme.

Mapa topograficzna z 1934 r., skala 1:25 000, arkusz 3077 Podgorz [Topographic map from 1934, the scale 1:25,000, sheet 3077 Podgorz], Reichsamt für Landesaufnahme.

Mapa topograficzna z 1936 r., skala 1:25 000, arkusz 2977 Thorn] Topographic map from 1936, scale 1:25,000, sheet 2977 Thorn, Reichsamt für Landesaufnahme.

Mapa topograficzna z 1963 r., skala 1:25 000, arkusz nr 5 [Topographic map from 1963, scale 1:25,000, sheet no. 5], Zarząd Topograficzny Sztabu Generalnego WP [the Topographic Board of the General Staff of the Polish Armed Forces], Warszawa.

Mapa topograficzna z 1963 r., skala 1:25 000, arkusz nr 8 [Topographic map from 1963, scale 1:25,000, sheet no. 8], Zarząd Topograficzny Sztabu Generalnego WP [the Topographic Board of the General Staff of the Polish Armed Forces], Warszawa.

Mapa topograficzna z 1971 r., skala 1:25 000, arkusz 355.14 Łysomice [Topographic map from 1971, scale 1:25,000, sheet 355.14 Łysomice], GUGiK, Warszawa.

Mapa topograficzna z 1971 r., skala 1:25 000, arkusz 355.32 Toruń [Topographic map from 1971, scale 1:25,000, sheet 355.32 Toruń], GUGiK, Warszawa. 
Mapa topograficzna z 1987 r., skala 1:25 000, arkusz N34-98-C-c Toruń [Topographic map from 1987, scale 1:25,000, sheet N-34-98-C-c Toruń], Sztab Generalny WP [the General Staff of the Polish Armed Forces], Warszawa.

Mapa topograficzna z 1987 r., skala 1:25 000, arkusz N34-110-A-a Podgórz [Topographic map from 1987, scale 1:25,000, sheet N-34-110-A-a Podgórz], Sztab Generalny WP [the General Staff of the Polish Armed Forces], Warszawa.

Mapa topograficzna z 2000 r., skala 1:10 000, arkusz N34-110-A-a-1 Mała Nieszawka [Topographic map from 2000, scale 1:10,000, sheet N-34-110-A-a-1 Mała Nieszawka], Główny Geodeta Kraju [the Surveyor General of Poland], Warszawa.

Melkowska M., 2009, Kształtowanie się zbiorowisk leśnych na poligonie artyleryjskim pod Toruniem, Praca magisterska, Uniwersytet Mikołaja Kopernika, Wydział BiNoZ, Instytut Ekologii i Ochrony Środowiska [Development of forest plant communities on the artillery range near the city of Torun, Master's thesis, Nicolaus Copernicus University, Faculty of Biology and Earth Sciences, Institute of Ecology and Environment Protection], Torun.

Nordberg M.-L. \& Everston J., 2003, Monitoring change in mountainous dry-heath vegetation at a regional scale using multitemporal Landsat TM data, Ambio 32(8): $502-509$

Plan miasta Toruń (skala oryginału 1:20 000) [Street plan of Torun (the original scale 1:20,000)], 1994, PPWK, Warszawa-Wrocław.

Plan miasta Toruń (skala oryginału 1:15 000) [Street plan of Torun (the original scale 1:15,000)], 1997, PPWK, Warszawa-Wrocław.

Plan miasta Torun (skala oryginału 1:20 000) [Street plan of Torun (the original scale 1:20,000)], 2000, Wyd. Daunpol, Warszawa, 2000, Warszawa.

Plan zagospodarowania przestrzennego osiedla JAR [The spatial development plan of the housing estate JAR], 2007, Miejska Pracownia Urbanistyczna UM Toruń [Urban Planning Laboratory of the Municipal Council of Toruń], Torun.

Rose R. J., Webb N. R., Clarke R. T. \& Traynor C. H., 2000, Changes on the heathlands in Dorset, England, between 1987 and 1996, Biological Conservation 93: 117-125.

Symonides E., 1974a, Populations of Spergula vernalis Willd. on dunes in the Torun Basin, Ekol. Pol. 22(2): $379-416$

Symonides E., 1974b, Morphological variability of Spergula vernalis Willd. from different dune biotopes of the Toruń Basin, Ekol. Pol. 22(2): 417-440.
Symonides E., 1974c, The phenology of Spergula vernalis Willd. in relation to microclimatic conditions. Ekol. Pol. 22(2): 441-456.

Symonides E., 1974d, The water economics of Spergula vernalis Willd. Ekol. Pol. 22(2): 457-472.

Symonides E., 1979a, The structure and population dynamics of psammophytes on inland dunes. I. Populations of initial stages, Ekol. Pol.27(1): 3-37.

Symonides E., 1979b, The structure and population dynamics of psammophytes on inland dunes. II. Loosesod populations, Ekol. Pol. 27(2): 191-234.

Symonides E., 1979c, The structure and population dynamics of psammophytes on inland dunes. III. Populations of compact psammophyte communities, Ekol. Pol. 27(2): 235-257.

Symonides E., 1985, Population structure of psammophile vegetation, [in:] J. White (ed.), The population Structure of Vegetation, Dr W. Junk Publishers, The Hague: 265-291.

Toruń - mapa turystyczna (skala oryginału 1:18 000) [Torun - tourist map (the original scale 1:18,000)], 2007,Wyd. Demart, Warszawa.

Tyszkiewicz J., 1976, Stalag XX a obóz jeńców wojennych w Toruniu w latach 1939-1945 [Stalag XX - a prisoners-of-war camp in Toruń in 1939 - 1945], Zapiski Historyczne XLI(1): 51-80.

Walas J., 1973, Szata roślinna Kotliny Toruńskiej [The vegetation cover of the Torun Basin], Acta Univ. Nicolai Copernici, Geografia 10: 161-186.

Wilkoń-Michalska J., 1971, Szata roślinna Kujaw. Przewodnik florystyczny [Vegetation cover of the Kujawy region, Floristic guidebook], TNT, Toruń.

Wilkoń-Michalska J. \& Symonides E., 1974, The influence of vegetation on the dynamics of soil humidity in the patch of Spergulo-Corynephoretum Tx. (1928) Libb. (1933, Fragm. Flor. Geobot. 20(4): 497-528.

Webb N. R., 1990, Changes on the Heathlands of Dorset, England, between 1978 and 1987, Biological Conservation 51: 273-286.

Webb N. R., 1998, The traditional management of European heathlands, Journal of Applied Ecology 35: 987 990.

Wojskowa mapa topograficzna z 2003 r., skala 1:25 000, arkusz N-34-98-C-C,D Torun - 1 [Poland military city maps from 2003, scale 1:25,000, sheet N-34-98C-C,D Torun - 1], Sztab Generalny WP [the General Staff of the Polish Armed Forces], Warszawa.

Veitch N., Webb N. R. \& Wyatt B. K., 1995, The application of Geographic Information Systems and remotely sensed data to the conservation of heathland fragments, Biological Conservation 72: 91-97. 